\title{
HYDATID CYST MORBIDITY IN ENDEMIC REGIONS OF THE COMMUNITY OF INDEPENDENT STATES: A MULTICENTER STUDY
}

Minaev S. V. ${ }^{1}$, Razin M. P. ${ }^{2}$, Axelrov M. A. ${ }^{3}$, Aydemirov A. N. ${ }^{1}$, Shamsiev A. M. ${ }^{4}$, Poluxov R. Sh. ${ }^{5}$, Tarakanov V. A. ${ }^{6}$, Shamsiev J. A. ${ }^{4}$, Vafin A. Z. 1 , Barova N. K. ${ }^{8}$, Mashchenko A. N. ${ }^{1}$, Tadibe A. V. ${ }^{7}$, Gerasimenko I. N. ${ }^{1}$

1 Stavropol State Medical University, Russian Federation

2 Kirov State Medical University, Russian Federation

${ }^{3}$ Tyumen State Medical University, Russian Federation

4 Samarkand State Medical Institute, Republic of Uzbekistan

${ }^{5}$ Azerbaijan Medical University, Baku, Republic of Azerbaijan

${ }^{6}$ Kuban State Medical University, Krasnodar, Russian Federation

7 Salekhard District Clinical Hospital, Russian Federation

8 Regional Children's Clinical Hospital, Krasnodar, Russian Federation

\section{ЗАБОАЕВАЕМОСТЬ ЭХИНОКОККОЗОМ В ЭНАЕМИЧНЫХ РЕГИОНАХ СТРАН СОАРУЖЕСТВА НЕЗАВИСИМЫХ ГОСУААРСТВ: МНОГОЦЕНТРОВОЕ ИССАЕАОВАНИЕ}

\author{
С. В. Минаев ${ }^{1}$, М. П. Разин ${ }^{2}$, М. А. Аксельров ${ }^{3}$, А. Н. АйАемиров ${ }^{1}$, \\ А. М. Шамсиев ${ }^{4}$, Р. Ш. Полухов ${ }^{5}$, В. А. Тараканов ${ }^{6}$, Ж. А. Шамсиев ${ }^{4}$, А. 3. Вафрин ${ }^{1}$, \\ Н. К. Барова ${ }^{8}$, А. Н. Мащенко ${ }^{1}$, А. В. Талибе ${ }^{7}$, И. Н. Герасименко ${ }^{1}$ \\ 1 Ставропольский госуАарственный меАицинский университет, \\ Российская ФеАерация \\ 2 Кировский госУАарственный МеАицинский университет, Российская ФеАерация \\ ${ }^{3}$ Тюменский госуАарственный МеАицинский университет, Российская ФеАерация \\ ${ }^{4}$ Самарканаский госуАарственныЙ МеАицинский институт, Республика Узбекистан \\ 5 АзербайАжанский меАицинский университет, Баку, Республика АзербайАжан \\ ${ }^{6}$ Кубанский госуАарственный МеАицинский университет, КрасноАар, \\ Российская ФеАерация \\ 7 Салехардская окружная клиническая больница, Российская Фелерация \\ 8 Краевая Аетская кАиническая больница, КрасноАар, Российская ФеАерация
}

We present findings of a multicenter study investigating incidence of hydatid cysts in endemic regions of the Community of Independent States (CIS). Transmission of hydatid cysts depends on agricultural activity. The highest incidence in the CIS was observed in Yamal-Nenets Autonomous District (4.2 \pm 0.36 and 4.5 \pm 1.1 per 100,000 adults) and Republic of Uzbekistan $(4.9 \pm 0.45$ and $4.3 \pm 0.5$ per 100,000 children). Among adults, hydatid cysts were more common among those aged $18-$ 40 years and in men (56.3-64.5\%), except in Stavropol Territory (43.4\%). Among children, boys (56.8-77.6\%) and children aged 10-14 years had higher incidence. Krasnodar Territory had the highest number of meat samples contaminated with Echinococcus cysts. Incidence of hydatid cysts showed different structures and frequencies throughout the CIS; incidence is likely underestimated in the official statistics. The data obtained indicate the need to improve specialized services, including creation of a population register, for the study of hydatid cysts.

Keywords: hydatid cyst, echinococcosis, morbidity, children, adults

Представлены данные мультицентрового исследования по заболеваемости эхинококкозом в эндемичных регионах СНГ. Определены пути передачи эхинококкоза в зависимости от сельскохозяйственной деятельности. Наиболее высокая заболеваемость в СНГ отмечалась в Ямало-Ненецком автономном округе и Республике Узбекистан (среди

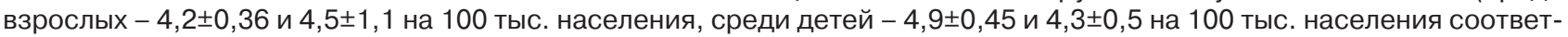
ственно). Среди взрослого населения эхинококкоз встречался чаще в возрастной группе от 18 до 40 лет с преобладанием мужчин (56,3-64,5 \%), за исключением Ставропольского края $(43,4 \%)$. Среди детского населения чаще болели мальчики $(56,8-77,6$ \%) в возрастной группе 10-14 лет. Наибольшее число положительных результатов исследования 
мяса на эхинококкоз регистрировалось в Краснодарском крае. Изучение заболеваемости эхинококкозом показало не только различную структуру и частоту его встречаемости на территории СНГ, но и недоучет заболеваемости в официальной статистике. Полученные данные указывают на необходимость совершенствования специализированной службы, включая создание популяционного регистра по изучению эхинококкоза.

Ключевые слова: эхинококкоз, заболеваемость, дети, взрослые

For citation: Minaev S. V., Razin M. P., Axelrov M. A., Aydemirov A. N., Shamsiev A. M., Poluxov R. Sh., Tarakanov V. A., Shamsiev J. A., Vafin A. Z., Barova N. K., Mashchenko A. N., Tadibe A. V., Gerasimenko I. N. HYDATID CYST MORBIDITY IN ENDEMIC REGIONS OF COUNTRIES OF THE COMMUNITY OF INDEPENDENT STATES: A MULTICENTER STUDY. MEdical News of the North Caucasus. 2018;13(3):453-458. DOI - https://doi.org/10.14300/mnnc.2018.13076

Для цитирования: Минаев С. В., Разин М. П., Аксельров М. А., Айдемиров А. Н., Шамсиев А. М., Полухов Р. Ш., Тараканов В. А., Шамсиев Ж. А., Вафин А. З., Барова Н. К., Мащенко А. Н., Тадибе А. В., Герасименко И. Н. ЗАБОЛЕВАЕМОСТЬ ЭХИНОКОККОЗОМ В ЭНДЕМИЧНЫХ РЕГИОНАХ СТРАН СОДРУЖЕСТВА НЕЗАВИСИМЫХ ГОСУДАРСТВ: МНОГОЦЕНТРОВОЕ ИССЛЕДОВАНИЕ. Медицинский вестник Северного Кавказа. 2018;13(3):453-458. DOI - https://doi.org/10.14300/mnnc.2018.13076

\author{
CIS - Community of Independent States \\ KT - Krasnodar Territory \\ RAz - Republic of Azerbaijan \\ RCHE - Republican Center for Hygiene and Epidemiology \\ RF - Russian Federation \\ RUz - Republic of Uzbekistan
}

\author{
SR - Samarkand Region \\ ST - Stavropol Territory \\ USA - United States of America \\ USSR - Union of Soviet Socialist Republics \\ WHO - World Health Organization \\ YaNAD - Yamal-Nenets Autonomous District
}

H uman echinococcosis refers to severe parasitic diseases that affect different strata of the population and different age groups [1, 2, 3]. Registration of this helminthiasis started in the USSR in 1983. According to the WHO [4], in some endemic areas, incidence rates of hydatid cysts fluctuate between 5-10 \% of the total population per year. Modern epidemiology of the disease is characterized by infection among people who are engaged in livestock production, as well as increasingly more frequent infection among urban populations [5]. The clinical importance of hydatid cysts is related to the severe clinical manifestations with multiple lesions of various organs, leading to long-term disability and death. In 2013, five deaths were recorded in the Altai and Krasnoyarsk territories and Kaliningrad Region; in 2014, two deaths occurred in the Altai Territory and Sverdlovsk Region; and there was one death in 2015 the Kurgan Region [6]. It is important to study the conditions of echinococcosis infection and to determine the dynamics of morbidity among children and adults, to clarify the most effective ways to prevent disease. It should be noted that not all cases of echinococcosis are included in the official statistics. In such cases, if rare cases among adults are undercounted, then there is not a single incidence of hydatid cyst recorded among children. Therefore, it is extremely important to conduct studies that take into account the incidence of hydatid cysts among all age groups.

The aim of the investigation was to conduct a multicenter study of the incidence of hydatid cysts among adults and children in endemic regions of the CIS.

Material and Methods. We conducted a retrospective epidemiological analysis of the incidence of hydatid cysts among adults and children in the CIS between 2000 and 2015. This analysis included cases of echinococcosis among populations in endemic regions of the CIS, based on data collected using Form N003/u, «Inpatient card»; Form N02, "Information on infectious and parasitic diseases»; and Form N357-u, "Card of the epidemiological examination of infectious disease outbreaks». The choice of medical institutions to include in this study was determined according to the concentration of patients with hydatid cysts registered in the databases of health facilities where operative treatment of hydatid cysts was carried out. The following institutions participated in the study: the Regional Center for the Prevention, Diagnosis, and Treatment of Echinococcosis of Regional Clinical Hospital, and Regional Children's Clinical Hospital, Stavropol, Russian Federation (RF); Salekhard District Clinical Hospital of the Health Department of the Yamalo-Nenets Autonomous District (YaNAD), RF; Research Institute - Regional Clinical Hospital № 1, named after Professor S. V. Ochapovsky, and Regional Children's Clinical Hospital, Krasnodar, RF; research project of the Samarkand Medical Institute ITD-1109-11,3-27357, «Development of methods for diagnosis, treatment and prevention, taking into account regional characteristics of maternal and child health", and the Second Clinic of the Samarkand Medical Institute, Republic of Uzbekistan (RUz); and the Educational and Surgical Center, Clinical Medical Center of the Azerbaijan Medical University in Baku, Republic of Azerbaijan (RAz). The data of population in the study areas was taken from the official data of the Territorial Bodies of the Federal State Statistics Service for the territories of the RF and the Republican Center for Hygiene and Epidemiology (RCHE).

To reveal the parasitic morbidity, the overall epidemiological indicator was determined per 100,000 population, specified by age group and subsequent distribution of patients by sex. We determined the direction of agricultural activity, the source of morbidity, the type of pathogen, as well as the index of organ damage (liver, lungs and combined forms).

Statistical analysis of the research data was carried out using Excel 2010 (Microsoft Corporation, USA) and Statistica 10.0 (StatSoft, Tulsa, OK, USA), using variational statistics methods and estimating the reliability of differences in quantitative indicators using a Student $t$-test.

Results and Discussion. According to our data, the number of cases of hydatid cyst in the endemic regions of the CIS from 2000 to 2015 varied by region. In Stavropol Territory (ST), RF, 187 patients with hydatid cysts were observed, including 153 adults (81.8\%) and 34 children $(18.2 \%)$. In Krasnodar Territory (KT), RF, the total number of cases was 88, including 76 adults $(86.4 \%)$ and 12 children (13.6\%). In the YaNAD (RF), 227 patients were treated: 171 adults $(75.3 \%)$ and 56 children $(24.7 \%)$. In the Samarkand Region (SR), RUz, 314 patients were treated, including 238 adults $(75.8 \%)$ and 76 children $24.2 \%$. The number of cases of hydatid cyst in the RAz was 1058 , including 637 adults $(60.2 \%)$ and 421 children 
(39.8\%). The distribution of cases of hydatid cyst among adults by sex was as follows (Fig. 1). In the ST (RF): 62 men $(43.4 \%)$ and 91 women $(56.6 \%)$; in the KT (RF): 49 men $(64.5 \%)$ and 27 women $(35.5 \%)$; in the YaNAD (RF): 109 men (63.7\%) and 62 women (36.3 \%); in the SR (RUz): 134 men (56.3 \%) and 104 women (43.7\%); and in the RAz: 403 men (63.3\%) and 234 women (36.7\%). Among children with hydatid cysts, the sex distribution was as follows (Fig. 2). In the ST: 21 boys (61.7\%) and 13 girls (38.3 \%); in the KT: 8 boys $(66.7 \%)$ and 4 girls (33.3\%); In the YaNAD: 39 boys (69.6\%) and 17 girls (30.4\%); in the SR (RUz): 59 boys ( $77.6 \%$ ) and 17 girls (22.4\%); and in the RAz: 239 boys (56.8\%) and 182 girls (43.2\%). The distribution by age group among the adult population revealed that most cases occurred in individuals aged 18-40 years. The number of cases in that age group, by region, was as follows. In the ST, 64 cases (41.8\%); in the KT, 43 (56.6\%); in the YaNAD, 81 (47.4\%); in the SR (RUz), 123 (51.7\%); and in the RAz, 389 cases (61.2\%). Among children, the distribution of cases by age group was as follows. In the ST (RF), there were 6 children age $3-7$ years (17.6\%), 7 children age $7-10$ years $(20.6 \%)$, 13 children age $10-14$ years (38.2 \%), and 8 children age $14-18$ years $(23.5 \%)$. In the KT (RF), there was 1 child age $3-7$ years $(11.1 \%), 4$ children age $7-10$ years (44.4\%), 3 children age $10-14$ years (33.3\%), and 1 child age $14-18$ years $(11.1 \%)$. In the YaNAD (RF), there were 9 children age $3-7$ years (16.1\%), 17 children age $7-10$ years $(30.4 \%), 16$ children age $10-14$ years $(28.6 \%)$, and 14 children age $14-18$ years $(25.0 \%)$. In the SR (RUz), there was 1 child age $3-7$ years $(1.3 \%), 6$ children age $7-10$ years $(7.9 \%), 26$ children age $10-14$ years $(34.2 \%)$, and 43 children age $14-18$ years $(56.6 \%)$. In the RAz, there were 6 children age 1-3 years (1.4\%), 63 children age $3-7$ years $(14.9 \%), 137$ children age $7-10$ years $(32.5 \%), 122$ children age $10-14$ years $(22.1 \%)$, and 93 children age $14-18$ years ( $29 \%)$.

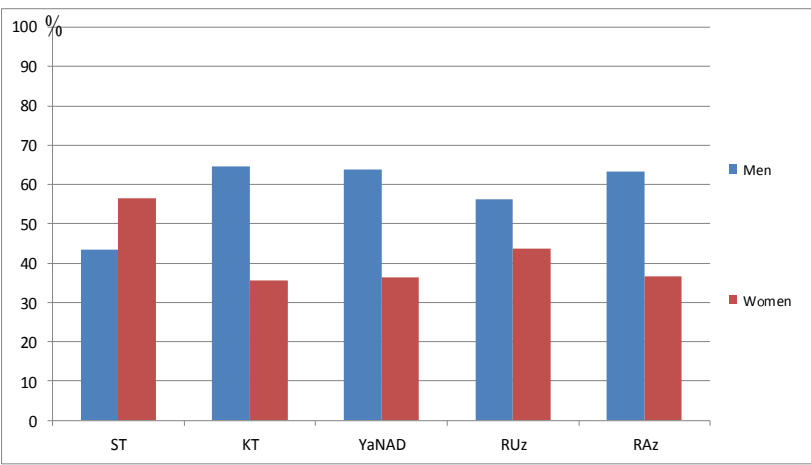

Fig. 1. Distribution of cases of hydatid cyst among adults, by sex

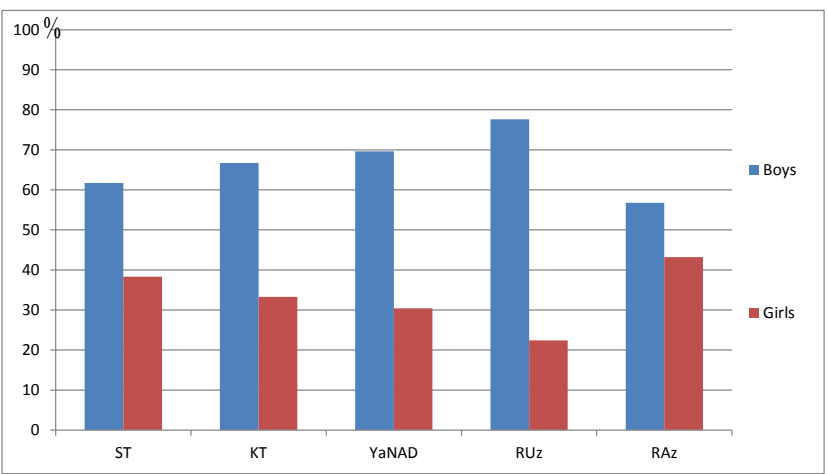

Fig. 2. Distribution of cases of hydatid cyst among children, by sex
Regarding the affected organ, hydatid cysts were recorded in adults as follows, for liver/lung/combined form/rare forms, respectively (Fig. 3). In the ST (RF): $91(58.3 \%) / 46(29.5 \%) / 16(10.3 \%) / 3(1.9 \%)$; in the KT (RF): $32(42.2 \%) / 28(36.8 \%) / 16(21 \%) / 0$; in YaNAD (RF): $52(30.4 \%) / 117(68.4 \%) / 2(1.2 \%) / 0$; in the SR (RUz): 192 (80.7\%)/34 (14.3\%)/12 (5.0\%)/0; in the RAz: $437(68.6 \%) / 134(21.0 \%) / 66(10.4 \%) / 0$. Among children, the distribution of organs affected (liver/lung/combined form) was as follows (Fig. 4). In the ST (RF): $17(50.0 \%) / 11(32.4 \%) / 6(17.6 \%)$; in the KT (RF): $8(66.7 \%) / 3(25 \%) / 1(8.3 \%)$; in the YaNAD (RF): $9(16.1 \%) / 47(83.9 \%) / 0$; in the SR (RUz): $36(47.4 \%) / 30(39.4 \%) / 10(13.2 \%)$; in the RAz $159(37.7 \%) / 173(41.1 \%) / 77(18.3 \%)$ and other sites, $12(2.9 \%)$.

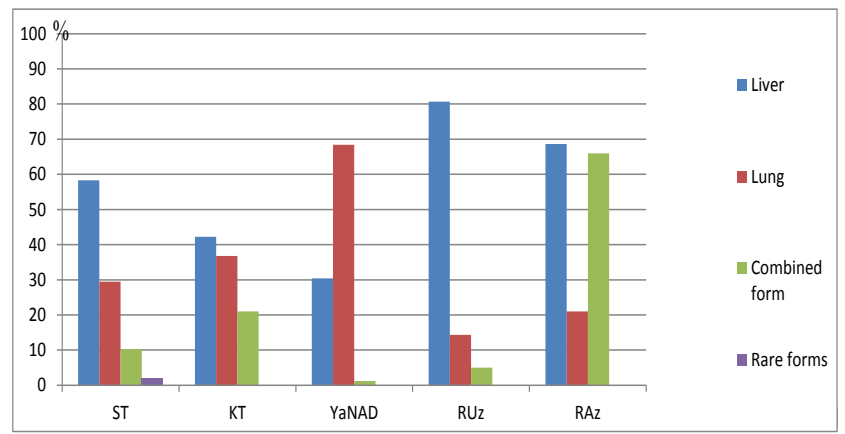

Fig. 3. Distribution of cases of hydatid cyst among adults, by affected organ

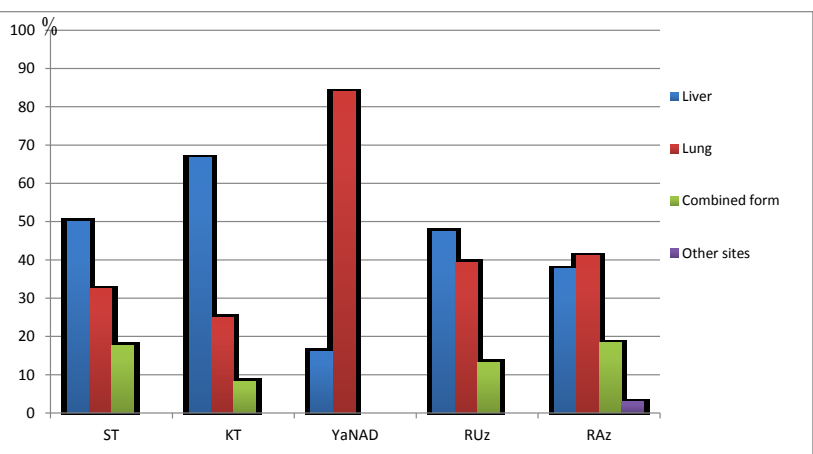

Fig.4. Distribution of cases of hydatid cyst in children, by affected organ

The total incidence of hydatid cysts during the study period, according to official statistics of the RF was 0.3-0.41 per 100,000 population. It should be noted that, compared with 1991, the incidence of echinococcosis increased nearly 4-fold, from 0.1 cases per 100,000 population $[6,7]$. In the ST (RF), according to official statistics, the total incidence of hydatid cysts in adults was $0.88 \pm 0.1$ per 100,000 ; in children, this was $0.49 \pm 0.2$ per $100,000[8,9]$. In the KT (RF), incidence was $0.058 \pm 0.09$ per 100,000 adults and $0.026 \pm 0.01$ per 100,000 children. In the YaNAD (RF), incidence was $3.35 \pm 0.23$ per 100,000 adults and $4.1 \pm 0.7$ per 100,000 children [10]. In the SR (RUz), the overall incidence of hydatid cysts was $3.9 \pm 1.6$ per 100,000 population [11]. According to the RCHE, the total incidence in the RAz was $2.9 \pm 1.5$ per 100,000 population [12].

According to updated data on the territories of the RF, the total incidence of hydatid cysts for the study period in the ST was $1.69 \pm 0.5$ per 100,000 adults and $0.63 \pm 0.3$ per 
100,000 children; in the $\mathrm{KT}$, this was $0.073 \pm 0.03$ per 100,000 adults and $0.03 \pm 0.02$ per 100,000 children; in the YaNAD, incidence was $4.2 \pm 0.36$ per 100,000 adults and $4.9 \pm 0.45$ per 100,000 children. In the SR (RUz), the incidence of hydatid cysts was $4.5 \pm 1.1$ per 100,000 adults and $4.3 \pm 0.5$ per 100,000 children. In the $\mathrm{RAz}$, the adjusted overall morbidity was $3.7 \pm 0.62$ per 100,000 adults and $3.9 \pm 0.38$ per 100,000 children.

Based on these results, when comparing the adjusted morbidity and data of the official reports, underestimation was present for cases of hydatid cyst among both children and adults in all study areas. The existing discrepancies in the results for general incidence testify to the incompleteness of the statistical data provided by health facilities to state bodies, including irregular or incomplete delivery of emergency notification cards by hospital surgical departments when diagnosing hydatid cysts. Another reason for the discrepancy is the migration process, wherein a number of patients are not taken into account owing to their residence in another territory.

According to Form N5 «Information on veterinary and sanitary expertise of raw materials and animal products", a total of 72,371 meat samples with Echinococcus eggs in 46 regions throughout the RF were identified in agricultural and meat markets [13, 14]. The percentage of contaminated meat from cattle was $2.3 \%, 3.5 \%$ from sheep, and $1.17 \%$ from pigs. Meat processing plants identified 183,955 meat samples with hydatid cysts in 44 regions of the RF. The percentage of contaminated meat from cattle was $4.02 \%, 2.47 \%$ from pigs, and $5.7 \%$ from sheep. The highest number of meat samples with hydatid cysts was found in the KT $(38,435)$; other data for meat contaminated with hydatid cysts included in the Orenburg $(25,056)$ and Rostov $(14,006)$ regions, ST (10884), and the Saratov (7076), Chelyabinsk (3977), Samara (7452), and Moscow (6237) regions. The most frequently infected animals were large cattle (48\%) and small cattle (32\%), with pigs accounting for $19 \%$ and horses $1 \%[15,16]$. The North Caucasus Federal District is the third leading region for cattle-breeding agriculture, with a total of 2,230,700 sheep, accounting for $9.1 \%$ of all sheep and goats in the RF. The main causes of echinococcosis include violation of the rules regarding the slaughter of farm animals, improper disposal of offal from slaughtered animals, untimely de-worming of dogs, and large populations of stray dogs [17, 18]. YaNAD is the main reindeer breeding region in Russia as well as worldwide. About 630,000 domesticated reindeer graze in the YaNAD, which is more than $52 \%$ of the total Russian population of these animals. Reindeer breeding employs up to 7000 people, mainly indigenous peoples of the YaNAD (Nenets, Khanty, and Komi-Zyryans). As in other regions where cattle breeding has been developed, helminthiases have a significant impact on the health of the population in the YaNAD, causing significant medical and social harm. The incidence of hydatid cysts among people engaged in reindeer herding is up to $30 \%$ [19]. In RUz and RAz, the leading sources of infection for humans include sheep (53.8\%), cattle (34.8\%), and pigs (6.7\%). A number of animal meat samples have been found to be contaminated with Echinococcus larvae, which can occur as a result of contact with the organs (lungs, liver) of other infected animals. According to data of the RCHE in Baku (RAz), causative agents of echinococcosis have been detected in the central water supply $[20,21]$.

According to some authors, the leading site of hydatid cysts is the lung (41-56\% of all localizations) [22]. According to other data, most hydatid cysts occur in the liver (41.9-65.9\%) [23]. The most common combined lesions are simultaneous hydatid cysts in the lung and liver, which affect $7.5-21 \%$ of infected children. Larrieu and Frider presented data from a survey of 9970 patients from regions of South America, Africa, Europe, Asia, and Australia, considered to be endemic zones of echinococcosis owing to shepherding traditions. Those authors estimated that the ratio of incidence of liver to lung infection is $2.5: 1$. They found a completely different situation when studying this ratio in individuals with asymptomatic forms of the disease. In ultrasound and radiographic examination of 10,000 apparently healthy people living in endemic zones of Argentina and Uruguay, the ratio of lesions in the liver and lungs was $6: 1$ and $12: 1$, respectively. This difference in the ratio of liver and lung damage between persons with preclinical forms of echinococcosis $(6: 1$ and $12: 1)$ and hospitalized patients $(2.5: 1)$ is attributable to the faster growth and earlier manifestation of clinical signs of pulmonary disease [24]. The third most common site of hydatid cysts is the spleen, which accounts for more than $6 \%$ of all abdominal forms of infection [25]. The incidence of pancreatic disease does not exceed $0.25 \%$. According to Dahniya et al. this localization of the parasite was detected in only 1 of 357 patients examined during a 20 -year period. One of the rarest sites of hydatid cysts is the kidney (1.5-5\% of observations), with only one kidney most often affected. As a rule, the oncosphere develops in the cortical layer of the kidney, and less often in the perirenal fat. Hydatid cysts of the kidney remain asymptomatic for a long period, and diagnosis is made only if the patient develops hydatiduria owing to rupture of the cyst. Cysts excreted in the urine have the appearance of grapes or a transparent necklace [26]. A rare manifestation is hydatid cysts in the brain, found in only $0.5-2.5 \%$ of all cases, according to various data $[27,28]$

Conclusions. The results of our multicenter study investigating the incidence of hydatid cysts in endemic regions of countries of the CIS revealed that incidence of echinococcosis differs both territorially as well as in the structure of overall morbidity. The lowest incidence of hydatid cysts among the adult population was found in the KT (RF), with $0.058 \pm 0.09$ per 100,000 population; the highest incidence was in the YaNAD (RF) with $4.2 \pm 0.36$ per 100,000 and the RUz with $4.5 \pm 1.1$ per 100,000 . With respect to age groups and sex, individuals aged $18-40$ years and men were the most often affected (56.3-64.5\%) in all regions studied. The predominant organ site of lesion was the liver, in $62.9 \%$ of cases; however, in the YaNAD, there was a pronounced prevalence of hydatid cysts of the lung (68.4\%). In the ST, there were three cases of extrahepatic abdominal multiple echinococcosis. The highest number of children affected were in the YaNAD (RF) and the RUz (4.9 \pm 0.45 and $4.3 \pm 0.5$ per 100,000 , respectively). As to the overall incidence rate, boys predominated (58.7-77.6 \%) and children aged $10-14$ years $(28.9 \%)$. In adults, hydatid cysts occurred in the liver in most cases $(50.4 \%)$. The obtained data showed a clear correlation with morbidity in the CIS countries, thereby leaving open the problem of studying morbidity indicators, which requires further observation.

A comparative assessment of the indicators of adjusted and official incidence in the CIS revealed underestimation of the number of patients with hydatid cysts of internal organs. These data testify to the need for more complete surveillance as well as needed improvement of specialized services in the CIS, including the possible creation of a population register, to further study the occurrence of hydatid cysts in the region. 


\section{Disclosures:}

The authors declare no conflict of interest.

Acknowledgment. We thank Analisa Avila, ELS, of Edanz Group (www.edanzediting.com/ac) for editing a draft of this manuscript.

\section{References}

1. Minaev S. V., Gerasimenko I. N., Bykov N. I., Timofeev S. V. Up-to-date approaches in treatment of hydatid disease of the liver in childhood. Vestn. Khir. Im. I. I. Grek. 2013;172(1):71-74. PMID: 23808232.

2. Guzeeva T. M. The state of incidence of parasitic diseases in the Russian Federation and tasks in conditions of service reorganization. Med. Parasitol. Parasit. Dis. 2008;(1):3-11.

3. Maschenko A. N., Gerasimenko I. N. Minaeva O S. Echinococcosis in childhood. Bulletin of a young scientist. 2017;(1):25-29.

4. World Health Organization. Echinococcosis. Fact Sheet. 8 February 2018. Available at: http://www.who.int/ en/news-room/fact-sheets/detail/echinococcosis. Accessed June 19, 2018

5. Abdiev T. A., Abdiev F. T., Alimzhanov Z. N. [et al.] Forecast of changes in the situation of echinococcosis among the population in Uzbekistan. Med. Parasitol. Parasit. Dis. 2000;2:53-54.

6. WHO Informal Working Group. International classification of ultrasound images in cystic echinococcosis for application in clinical and field epidemiological settings. Acta Tropica. 2003;85(2):253-261.

7. Minaev S. V., Gerasimenko I. N., Gudiev Ch. G. New approaches in the treatment of liver echinococcosis in children. Pract. Med. 2012;(3):158-160.

8. Minaev S. V., Mashchenko A. N., Aydemirov A. N., Anisimov I. N., Gerasimenko I. N. [et al.] Epidemiological Characteristics of Echinococcosis in Adults and Paediatric Populations of Stavropol Region. Doctor Ru. 2018;7(151):35-38. https://doi.org/10.31550/1727-2378-2018-151-7-35-38

9. Vafin A. Z., Aidemirov A. N., Abdokov A. D., Popov A. V., Mashurova E. V. [et al.] Aparasitism and antiparasitism principle in liver echinococcosis surgery: results. Medicinskii vestnik Severnogo Kavkaza (Medical News of North Caucasus). 2014;9:121-124. https://doi.org/10.14300/mnnc.2014.09034

10. Utenko E. O., Baramzina S. V., Oparina L. V. Epidemiology of echinococcosis in the Northern Region of Russia. Epidemiol. Infect. Dis. 2018;1:27-32.

11. Shamsiev J. A. Puti uluchshenija rezul'tatov hirurgicheskogo lechenija i profilaktiki recidivov jehinokokkoza u detej: dis. ... d-ra med. nauk. Tashkent, 2015.

12. Mirzoev D. S. Optimization of the treatment of liver echinococcosis by subdiaphragmal localization in children. Author's abstract. dis. ... cand. sciences. Dushanbe, 2011;25

13. Letter of the Federal Service for Supervision of Consumer Rights Protection and Human Well-being of June 20, 2016 $\mathrm{H} 01 / 7782-16-27$. About the incidence of echinococcosis and alveococcosis in the Russian Federation.

14. Rozhin K. A., Khristianovsky P. I. Dynamics of epizootic the process of echinococcosis in the Russian Federation and
Orenburg region. Bull. Orenburg. Sci. Cent. URORAN. 2014;1.

Available at: http://elmag uran ru Accessed 05.05.2018.

15. Nelson I., Enrico B. Cystic echinococcosis. J. Clin. Microbiol. 2016:54(3);518-523.

https://doi.org/10.1128/JCM.02420-15

16. Marcinkute A., Sarkunas M., Moks E., Saarma U., Jokelainen P. [et al.] Echinococcus infections in the Baltic region. Vet. Parasitol. 2015;213:121-31.

https://doi.org/10.1016/j.vetpar.2015.07.032

17. Minaev S. V., Gerasimenko I. N., Kirgizov I. V., Shamsiev A. M., Bykov N. I. [et al.] Laparoscopic Treatment in Children with Hydatid Cyst of the Liver. World J. Surg. 2017;41(12):3218-3223.

https://doi.org/10.1007/s00268-017-4129-x

18. Gomez I., Gavara C. Review of the treatment of liver hydatid cysts. World J. Gastroenterol. 2015;21:124-131. https://doi.org/10.3748/wjg.v21.i1.124

19. Trishin M. V., Gureyeva P. V., Sim I. A. Epidemiologiya i diagnostika ekhinokokkoza sredi detskogo naseleniya v Orenburgskoy oblasti za 1994-2012 gg. Byulleten Orenburgskogo nauchnogo tsentra. 2014;1. Available at: http://elmag.uran.ru:9673/magazine/Numbers/2014-1 Accessed 05.05.2018.

20. Gawor J. Alveolar Echinococcosis in Europe and Poland. Threats to humans. Przegl Epidemiol. 2016;70(2):281288.

21. Shangareyeva R. Kh. Echinococcosis of the liver in children. The role of preserving - effective therapy. Pract. Med. 2014;1(77):78-83.

22. Gumerov A. A., Tkachenko T. N., Shangareyeva R. Kh. Complex treatment of echinococcosis in children. Surgery 2010;1:25-29.

23. Aliev M. M., Allaberganov A. T., Ikramov A. I., Sobirzhanov N. R. Some aspects of diagnosis and treatment of multiple liver echinococcosis in children. Surg. Uzbekistan. 2000;2:11-14.

24. Larrieu E. J., Frider B. Human cystic echinococcosis: contributions to the natural history of the disease. Ann. Trop. Med. Parasitol. 2001;95:679-687.

25. Artikov Zh. B. Choice and optimization of surgical tactics for echinococcosis of the spleen with the use of modern diagnostic technologies. Author's abstract. dis. ... cand. med. sciences. Tashkent, 2011:24.

26. Sehgal N., Priyadarshi V. Beware! A simple renal cyst could be a hydatid cyst. Urol. Ann. 2017;9:281-284. https://doi.org/10.4103/0974-7796.210028

27. Toro A., Schembari E., Mattone E., Di Carlo I. Hydatid Cyst of the Liver: A Challenge that can be Amplified Shifting from Open to Laparoscopic Surgery. World. J. Surg. 2018;42(9):2383-2383 https://doi.org/10.1007/s00268-018-4484-2

28. Agudelo Higuita N. I., Brunetti E., McCloskey C. Cystic echinococcosis. J. Clin. Microbiol. 2016;54:518-523. https://doi.org/10.1128/JCM.02420-15

\footnotetext{
About authors:

Minaev Sergey Viktorovich, MD, PhD, Professor, Head of the Department of Pediatric Surgery; tel.: +79624507653; e-mail: sminaev@yandex.ru

Razin Maksim Petrovich, MD, PhD, Professor, Head of the Department of Pediatric Surgery; tel.: +79128281527; e-mail: mprazin@yandex.ru

Axelrov Mikhail Alexandrovich, MD, PhD, Professor, Head of the Department of Pediatric Surgery; tel.: +79292694933; e-mail: akselerov@mail.ru

Aydemirov Arthur Nasirovich, MD, PhD, Professor, Head of the Department of Hospital Surgery tel.: +79624479697; e-mail: surgdis1@stgmu.ru

Shamsiev Azamat Muhitdinovich, MD, PhD, Professor, Rector; tel.: +998662335416; e-mail: samgmi@umail.uz Poluxov Ramiz Shamil-ogly, MD, PhD, Associate Professor, Head of the Department of Pediatric Surgery; tel.: +994503162699; e-mail: ramizpoluxov@mail.ru
} 
Tarakanov Victor Alexandrovich, MD, PhD, Professor, Head of the Department of Pediatric Surgery; tel.: +78612685290; e-mail: nbarova@yandex.ru

Shamsiev Jamshid Azamatovich, MD, PhD, Professor, Head of the Department of Pediatric Surgery; tel.: +998979100041; e-mail: shamsiyevja@mail.ru

Vafin Albert Zakirovich, MD, PhD, Professor, Professor of Department of Hospital Surgery; tel.: +79034168319; e-mail: azvafin@mail.ru Barova Natusya Kaplanovna, MD, Head of Surgery Department № 1; tel.: +79882459207; e-mail: nbarova@yandex.ru

Mashchenko Alina Nikolaevna, Post-graduate student in the Department of Pediatric Surgery; tel.: +79633877244; e-mail: alina.mashchenko@mail.ru

Tadibe Anatoly Vladimirovich, MD, Pediatric surgeon in the surgical department of Salekhard District Clinical Hospital, Chief children's surgeon in the Health Department of Yamal-Nenets Autonomous District; tel.: +79044751716; e-mail: tadibe-av@okb89.ru

Gerasimenko Igor Nikolaevich, MD, Assistant in the Department of Pediatric Surgery; tel.: +79187704217; e-mail: igor9551@yandex.ru

(C) Group of authors, 2018

UDC 61:616.61

DOI - https://doi.org/10.14300/mnnc.2018.13077

ISSN - 2073-8137

\title{
INFLUENCE OF ANEMIA ON QUALITY OF LIFE IN PATIENTS WITH CHRONIC KIDNEY DESEASE ON RENAL REPLACEMENT THERAPY
}

\author{
Urazlina S. E., Zhdanova T. V., Nazarov A. V., Zueva T. V.
}

Ural State Medical University, Yekaterinburg, Russian Federation

\section{ВАИЯНИЕ АНЕМИИ НА КАЧЕСТВО ЖИЗНИ У ПАЦИЕНТОВ С ХРОНИЧЕСКОЙ БОАЕЗНЬЮ ПОЧЕК, ПОАУЧАЮЩИХ ЗАМЕСТИТЕАЬНУЮ ПОЧЕЧНУЮ ТЕРАПИЮ}

\author{
С. Е. Уразлина, Т. В. ЖАанова, А. В. Назаров, Т. В. Зуева \\ Уральский госуАарственный меАицинский университет, Екатеринбург, \\ Российская ФеАерация
}

\begin{abstract}
The influence of anemia and renal replacement therapy (RRT) on the quality of life (QOL) of patients with chronic kidney diseases (CKD) on HD, CAPD and kidney transplant recipients has been studied. 60 patients with CKD 5 were included in the study. Patients with CKD 3 were included in control group. It was found that the scores of QOL in the group of kidney transplant recipients were comparable with the scores in the group with CKD 3, and were better than in dialysis patients, not only in terms of physical health (PF and $\mathrm{PCH}$ ), but also in the terms of the psychological component of health (VT and SF). Reliable $(p<0.05)$ positive correlation have been obtained between $Q O L$ and hemoglobin levels $(P F, P C H, S F, M H)$, hematocrit (PF, PCH, SF, MH), serum iron level (PF, RP, BP, GH, PCH, VT, SF, MH), transferrin saturation index (BP, GH, PCH, VT, MH). Scores of QOL in the group of kidney transplant recipients and in the control group were comparable and were better than in the groups of patients on dialysis. Relationship between indices of anemia and QOL in patients on RRT was revealed.
\end{abstract}

\footnotetext{
Keywords: quality of life, chronic kidney disease, renal replacement therapy, anemia
}

Изучено влияние анемии и заместительной почечной терапии (ЗПТ) на качество жизни (КЖ) пациентов с хронической болезнью почек (ХБП), получающих гемодиализ (ГД), постоянный амбулаторный перитонеальный диализ (ПАПД), и реципиентов аллотрансплантации почки (АТП). В исследование были включены 60 пациентов с ХБП 5, которые были разделены на группы в зависимости от метода ЗПТ. Группу контроля составили пациенты с ХБП 3. Выявлено, что КЖ в группе реципиентов АТП было сопоставимо с оценками в группе пациентов с ХБП 3 и лучше, чем у пациентов, получающих диализ, не только по показателям физического здоровья (PF и ФКЗ), но и по показателям психологического здоровья (VT и SF). Достоверная положительная корреляция была выявлена между показателями КЖ и уровнем гемоглобина (PF, ФКЗ, SF, MH), гематокрита (PF, ФКЗ, SF, MH), сывороточного железа (PF, RP, BP, GH, ФКЗ, VT, SF, MH), индекса насыщения трансферрина (BP, GH, ФКЗ, VT, МH). Показатели КЖ в группе реципиентов АТП и в контрольной группе были сопоставимы и лучше, чем в группах пациентов, получающих диализ. Была выявлена взаимосвязь между показателями анемии и КЖ у пациентов, получающих ЗПТ.

Ключевые слова: качество жизни, хроническая почечная недостаточность, заместительная почечная терапия, анемический синдром 